\title{
P20. Lack of T cell exhaustion in acute myeloid leukaemia
}

\author{
FM Schnorfeil $^{1 *}$, FS Lichtenegger ${ }^{1}$, K Emmerig $^{1}$, M Schlüter ${ }^{1}$, R Draenert $^{2}$, W Hiddemann $^{3}$, M Subklewe $^{3}$ \\ From 1st Immunotherapy of Cancer Conference (ITOC1) \\ Munich, Germany. 12-14 March 2014
}

The prognosis of acute myeloid leukemia (AML), particularly when associated with adverse chromosomal or molecular aberrations, is poor due to a high relapse rate after induction chemotherapy. Postremission therapy for elimination of minimal residual disease remains a major challenge. Immunotherapeutic strategies aim at the stimulation of AML-specific immunity, especially of $\mathrm{CD}^{+} \mathrm{T}$ cells. However, the functionality of these cells in AML patients is not well described. T cell exhaustion has been suggested to contribute to immune evasion in various solid and haematological malignancies. Primarily demonstrated in chronic viral infections, exhausted $\mathrm{T}$ cells are characterised by an increased expression of several inhibitory molecules, reduced proliferation and an impaired capability of cytokine secretion and cytotoxicity.

To characterise $\mathrm{T}$ cell exhaustion in AML, we assessed the phenotype and effector function of $\mathrm{CD} 8^{+}$and $\mathrm{CD} 4^{+}$ $\mathrm{T}$ cells by flow cytometry. $\mathrm{T}$ cells from patients at primary diagnosis, with refractory disease, at relapse and at relapse after allogeneic stem cell transplantation (alloSCT) were analysed for surface expression of CD244, CD160, PD-1, TIM-3 and LAG-3. T cell proliferation and production of the cytokines IFN- $\gamma$, TNF- $\alpha$ and IL-2 were measured in response to different stimuli. Results were compared to healthy controls (HCs), while untreated HIV-infected patients served as positive controls for an exhausted $\mathrm{T}$ cell state.

In HIV-infected patients, we observed a pronounced upregulation of the inhibitory molecules CD244, CD160 and PD- 1 on $\mathrm{CD}^{+}$and $\mathrm{CD} 8^{+} \mathrm{T}$ cells as well as globally impaired cytokine production, clearly indicating $\mathrm{T}$ cell exhaustion. In contrast, $\mathrm{T}$ cells from AML patients showed an expression pattern of inhibitory surface molecules that was similar to $\mathrm{T}$ cells from age-matched HCs. AML

${ }^{1}$ Helmholtz Institute Munich, Clinical Cooperation Group Immunotherapy, Munich, Germany

Full list of author information is available at the end of the article patients with a relapse after alloSCT, however, showed remarkably high PD-1 expression on $\mathrm{CD}^{+}$and $\mathrm{CD} 8^{+}$ $\mathrm{T}$ cells, accompanied by a shift from naive to memory $\mathrm{T}$ cells. Functionally, no defect in $\mathrm{T}$ cell proliferation in any of the AML patient cohorts was detected. Of note, however, we observed a 2 -fold decrease in IFN- $\gamma$ production by $\mathrm{CD} 4^{+}$ $\mathrm{T}$ cells exclusively in patients at primary diagnosis.

Thus, T cells of AML patients are fully functional. Immunotherapies that aim at eliciting tumour-specific immune responses, e.g. dendritic cell based vaccines, may therefore be particularly suited for AML treatment.

\section{Authors' details}

${ }^{1}$ Helmholtz Institute Munich, Clinical Cooperation Group Immunotherapy, Munich, Germany. ${ }^{2}$ Klinikum der Universität München, Department of Internal Medicine IV, Munich, Germany. ${ }^{3}$ Klinikum der Universität München, Department of Internal Medicine III, Munich, Germany.

Published: 12 March 2014

\section{doi:10.1186/2051-1426-2-S2-P11}

Cite this article as: Schnorfeil et al.: P20. Lack of T cell exhaustion in acute myeloid leukaemia. Journal for ImmunoTherapy of Cancer 2014 2(Suppl 2):P11.

Submit your next manuscript to BioMed Central and take full advantage of:

- Convenient online submission

- Thorough peer review

- No space constraints or color figure charges

- Immediate publication on acceptance

- Inclusion in PubMed, CAS, Scopus and Google Scholar

- Research which is freely available for redistribution 